\title{
On-Road Use of Fischer-Tropsch Diesel Blends
}

Nigel Clark, Mridul Gautam, Donald Lyons, Chris Atkinson and Wenwei Xie

West Virginia Univ

Paul Norton and Keith Vertin National Renewable Energy Laboratory

Stephen Goguen and James Eberhardt

U. S. Department of Energy 
SAE routinely stocks printed papers for a period of three years following date of publication. Direct your orders to SAE Customer Sales and Satisfaction Department.

Quantity reprint rates can be obtained from the Customer Sales and Satisfaction Department.

To request permission to reprint a technical paper or permission to use copyrighted SAE publications in other works, contact the SAE Publications Group.

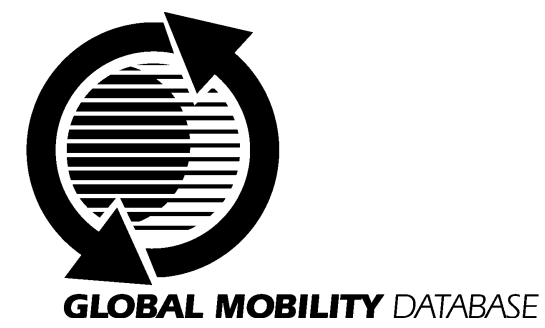

AII SAE papers, standards, and selected books are abstracted and indexed in the Global Mobility Database

\section{ISSN 0148-7191}

Positions and opinions advanced in this paper are those of the author(s) and not necessarily those of SAE. The author is solely responsible for the content of the paper. A process is available by which discussions will be printed with the paper if it is published in SAE Transactions. For permission to publish this paper in full or in part, contact the SAE Publications Group.

Persons wishing to submit papers to be considered for presentation or publication through SAE should send the manuscript or a 300 word abstract of a proposed manuscript to: Secretary, Engineering Meetings Board, SAE.

\section{Printed in USA}




\title{
On-Road Use of Fischer-Tropsch Diesel Blends
}

\author{
Nigel Clark, Mridul Gautam, Donald Lyons, Chris Atkinson and Wenwei Xie \\ West Virginia Univ
}

\author{
Paul Norton and Keith Vertin \\ National Renewable Energy Laboratory
}

Stephen Goguen and James Eberhardt

U. S. Department of Energy

Copyright (C) 1999 Society of Automotive Engineers, Inc.

\begin{abstract}
Alternative compression ignition engine fuels are of interest both to reduce emissions and to reduce U.S. petroleum fuel demand. A Malaysian Fischer-Tropsch gas-to-liquid fuel was compared with California \#2 diesel by characterizing emissions from over the road Class 8 tractors with Caterpillar 3176 engines, using a chassis dynamometer and full scale dilution tunnel. The 5-Mile route was employed as the test schedule, with a test weight of $42,000 \mathrm{lb}$. Levels of oxides of nitrogen $\left(\mathrm{NO}_{\mathrm{x}}\right)$ were reduced by an average of $12 \%$ and particulate matter (PM) by $25 \%$ for the Fischer-Tropsch fuel over the California diesel fuel. Another distillate fuel produced catalytically from Fischer-Tropsch products originally derived from natural gas by Mossgas was also compared with 49-state \#2 diesel by characterizing emissions from Detroit Diesel 6V-92 powered transit buses, three of them equipped with catalytic converters and rebuilt engines, and three without. The CBD cycle was employed as the test schedule, with a test weight of $33,050 \mathrm{lb}$. For those buses with catalytic converters and rebuilt engines, $\mathrm{NO}_{\mathrm{x}}$ was reduced by $8 \%$ and PM was reduced by $31 \%$ on average, while for those buses without, $\mathrm{NO}_{\mathrm{x}}$ was reduced by $5 \%$ and PM was reduced by $20 \%$ on average. It is concluded that advanced compression ignition fuels from non-petroleum sources can offer environmental advantages in typical line haul and city transit applications.
\end{abstract}

\section{INTRODUCTION AND PRIOR LITERATURE}

Compression ignition diesel engines offer the benefit of excellent fuel economy, but present the environmental disadvantage of emitting oxides of nitrogen $\left(\mathrm{NO}_{\mathrm{x}}\right)$ and particulate matter (PM) at a level that raises public concern. Oxides of nitrogen contribute ultimately to the formation of smog, while PM has been implicated as a threat to human health. Spark-ignited natural gas engines are offered as an alternative to diesel engines, but they still do not enjoy the fuel economy associated with unthrottled operation, and the fuel cylinders or tanks used for on board compressed or liquefied natural gas storage are still more cumbersome than liquid fuel tanks. Diesel fuel also offers high fuel energy density and diesel engines, following years of development, enjoy high reliability. For these reasons, diesel engines dominate the heavy duty fleet and are targeted for light truck and sport utility vehicle application.

Diesel engine PM emissions can be reduced through engine modifications, such as an increase in injection pressure, improvement in injector spray pattern, and alteration of charge motion. $\mathrm{NO}_{x}$ may be reduced by retarding the injection timing, or by employing exhaust gas recirculation. Aftertreatment devices may also be employed to oxidize exhaust constituents, but "lean $\mathrm{NO}_{x}$ " catalysts are still not established for aftertreatment.

There is benefit to reducing emissions through the reformulation of compression ignition fuels, or the adoption of suitable compression ignition fuels from nontraditional sources. This is particularly desirable if these fuels can be employed successfully in existing engines with no modifications, or with modifications only to the injection timing. Research has been conducted previously to support the use of "biodiesel", usually a methyl soy ester [1], [2]. Blends of biodiesel with diesel generally raise $\mathrm{NO}_{x}$ emissions slightly while reducing $\mathrm{PM}$ emissions substantially, but the widespread adoption of biodiesel is proscribed by its present market price.

It is well documented that changing the formulation of petroleum-based diesel fuel can also affect $\mathrm{PM}$ and $\mathrm{NO}_{\mathrm{x}}$ emissions, and this has been the motivation in reducing sulfur content of US diesel and by the State of California in adopting a diesel that is expected to produce lower emissions than diesel in the remaining 49 states. Reducing the sulfur content will reduce PM mass by reducing the solid sulfates produced. Mann et al. [3] 
reported data for a 2 liter Rover automobile diesel engine operating on seven different fuels. With the engine controls operating as received, PM was reduced when lower density fuels were used, whereas $\mathrm{NO}_{x}$ was increased. However, this work proceeded to show that results might be attributed to interactions between the combustion behavior of the fuels and the engine controls that were optimized for one fuel. For example, kerosene, representing a light fuel, suffered an ignition delay of over 0.3 degrees of crank angle relative to a dense diesel fuel merely due to its physical properties such as viscosity and density. Of course, energy densities and carbonhydrogen ratio in the fuel can also alter the full power rating of the engine.

Ultra-low-sulfur $(<0.005 \%)$ diesel fuels are being considered in Europe to reduce the PM levels from urban buses [4]. A $32 \%$ to $44 \%$ reduction in PM was obtained in buses with pre-EURO 1 engines and approximately $32 \%$ reduction in PM was obtained in buses with EURO 2 engines, while using ultra-low-sulfur European "City" diesel.

There has been recent interest in the combustion of liquid fuels produced from natural gas in compression ignition engines. Such Fischer-Tropsch fuels have been produced in Malaysia (FT-SMD) and diesel fuel has been produced from natural gas in South Africa (FT-MGCOD). Mossgas produces gasoline, diesel and other distillate fuels from natural gas, using a Fischer-Tropsch synthesis process. The natural gas feedstock (predominantly methane) is reformed using steam and oxygen into synthesis gas (carbon monoxide and hydrogen). This stream is then fed into a high temperature circulating fluidized bed reactor, employing an iron-based FischerTropsch (FT) catalyst (the Synthol process) to produce a light synthetic oil, which is then further treated and refined to give the desired product slate. The high temperature FT process produces a wider product spectrum than comparable low temperature slurry-phase processes, including a fraction of relatively light olefinic hydrocarbons. In the Mossgas process, this olefinic material is then converted to a middle distillate fuel through a secondary catalytic process ( Conversion of Olefins to Diesel), using a zeolite-based catalyst and employing further hydrotreating. The resulting fuel, termed COD, is slightly lower in cetane number (51.4 vs. 53.3), and lower in aromatic content (10.1\% vs. $16.9 \%)$ than the straight-run FT distillate fuel that is Mossgas' main product.

A recent report by Sirman et al. [5] detailed the emissions behavior of certification diesel and six alternative compression ignition fuels in an unmodified, direct injection 2.2 liter Daimler-Benz OM 611 diesel engine operating at seven steady-state speed and load points. It was recognized that by using absolute speed-load points, a comparison of the emissions can be made based on differences in fuel consumption and chemistry, not on power variations due to fuel density variations. Data showed a reduction in $\mathrm{PM}$ by $37 \%$ relative to a \#2 diesel, with a $6 \%$ reduction in $\mathrm{NO}_{\mathrm{x}}$. A $20 \%$ blend of FischerTropsch fuel with diesel showed a 27\% PM benefit.

Two South African Fischer-Tropsch fuels have been compared by Schaberg et al. [6] with California diesel fuel and federal diesel fuel, using a Detroit Diesel Series 60 engine under hot transient test conditions. The two novel fuels had substantially lower $\mathrm{NO}_{\mathrm{x}}$ emissions than the federal diesel fuel, and were each over $14 \%$ lower on $\mathrm{NO}_{\mathrm{x}}$ emissions than the California diesel fuel. The PM values for the Fischer-Tropsch fuels were each more than $20 \%$ lower than for the California diesel.

Preliminary engine studies have therefore shown that Fischer-Tropsch fuels offer an attractive alternative to conventional petroleum-based diesel fuels. However, it is also desirable to validate these fuels using field studies of in-service vehicles. Chassis dynamometer based emissions characterizations of Class 8 trucks running on California diesel and Fischer-Tropsch fuels are presented below. A further comparison using a fleet of city buses is also presented. This paper condenses and presents data discussed in three former SAE publications. [7, 8, 9]

\section{TRANSPORTABLE LABORATORIES}

The two West Virginia University Transportable Heavy Duty Vehicle Emissions Testing Laboratories are heavy duty chassis dynamometer systems that can be moved from site to site with a dedicated semi-trailer and a laboratory trailer. These laboratories were constructed with funding from the U. S. Department of Energy, Office of Transportation Technologies, and emissions data gathered by the laboratories are added to a database (http://www.afdc.nrel.gov/web_view/emishdv.html)

maintained by the National Renewable Energy Laboratory (NREL), in Golden, Colorado. Using selectable flywheels and air-cooled eddy current power absorbers, both inertia and road load losses, including wind drag and rolling resistance, are simulated by the laboratories. Power is taken directly from the drivewheels of the tested vehicle via hub adapters while the vehicle runs on free-spinning rollers. Besides hub torque, vehicle speed, and engine speed, gaseous emissions data can be logged continuously during a test through use of a full scale exhaust dilution tunnel, with heated probes and sample lines and analyzers for carbon monoxide (CO), oxides of nitrogen $\left(\mathrm{NO}_{\mathrm{x}}\right)$ and hydrocarbons $(\mathrm{HC})$. Particulate matter $(P M)$ is determined gravimetrically by collecting the PM on $70 \mathrm{~mm}$ diameter filters

The first laboratory, described by Clark et al. [10], differs from the second, largely in the positioning of the dilution tunnel and in some aspects of the drivetrain which couples the vehicle to the power absorbers. The two laboratories have previously been correlated with one another, and both laboratories were used in this research.

The chassis test cycles adopted for use by the laboratories were in this case for the purpose of comparing the alternative and conventional fuels. Class 8 
trucks and tractors, particularly those with unsynchronized manual transmissions, are generally unable to meet the acceleration requirements of the Central Business District cycle (which appears in SAE recommended practice $\mathrm{J1376}$ ) that is commonly used for transit buses. To satisfy the need for a cycle for heavy truck testing, Clark, et al. [11] proposed a "WVU 5 peak truck cycle" which was subsequently used by the Transportable Laboratories. The cycle covers a distance of 5 miles. More recently, this 5-peak cycle was replaced by a schedule termed the 5-Mile route, in which maximum acceleration is demanded of the truck during acceleration portions of the schedule. Figure 1 shows the actual speed vs. time trace of the 5-Mile route test for one of the diesel trucks in the study. The vehicle is customarily loaded to account for wind drag and tire losses in accordance with Federal code (Code of Federal Regulations, 1996) and inertia is simulated at $70 \%$ of the gross vehicle weight (GVW) for GVW up to $60,000 \mathrm{lb}$ $(27,200 \mathrm{~kg})$ and at $42,000 \mathrm{lb}(19,000 \mathrm{~kg})$ for vehicles with a GVW over $60,000 \mathrm{lb}(27,200 \mathrm{~kg})$ [12]. For the $80,000 \mathrm{lb}$ vehicles in this study, as discussed below, the weight was therefore $42,000 \mathrm{lb}$. at time of test. A "warm up" peak is usually included prior to the start of data logging test cycle. In the present research, the 5-Mile route was used for the trucks and the CBD cycle for the buses.

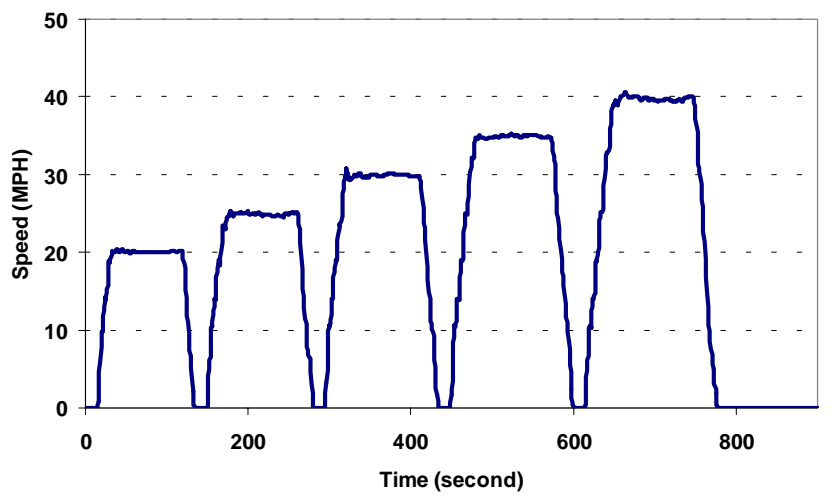

Figure 1. Actual speed vs. time for Pima Gro diesel truck on the 5-Mile route

\section{DESCRIPTION OF SUBJECT VEHICLES}

Both trucks and buses were employed in this test program. The trucks used in this study were model year 1992 to 1994 White-GMC WG64T class 8 tractors (80,000 lb gross vehicle weight) operated by Pima Gro Systems, Inc. in Southern California. The trucks were repowered with 1996 to 1997 Caterpillar 3176B diesel engines. Two of the five trucks in the study were converted by Power System Associates (PSA) for dualfuel compressed natural gas/diesel operation. However, in this paper, no dual fuel data have been presented and the dual fuel trucks were operated in the "diesel only" mode. One of the dual-fuel trucks is show in Figure 2.

The Caterpillar 3176B is an in-line, six-cylinder, 10.3-liter electronically controlled engine. Both the diesel and dual- fuel engines tested in this program were rated at 350 horsepower. All of these trucks were tested with California \#2 Diesel (CAD), four were tested with 100\% Malaysia Fischer-Tropsch diesel fuel (FT-SMD), and three of them were tested with a 50/50 blend of these two fuels (FT-SMD50/CAD50).

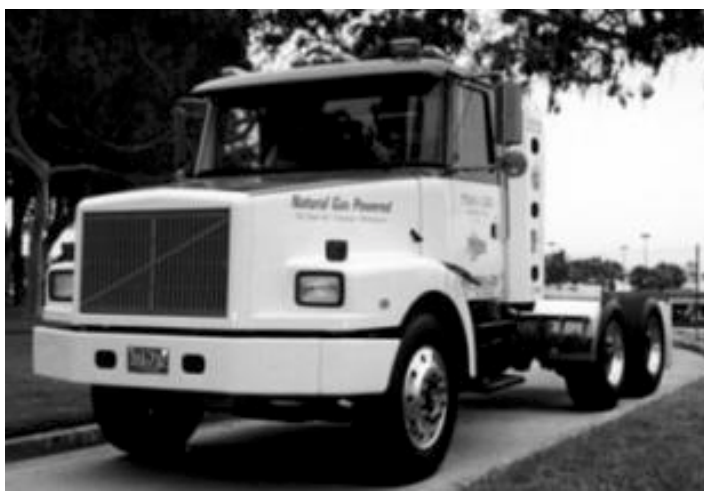

Figure 2. Pima Gro Inc. Dual-Fuel CNG/Diesel truck

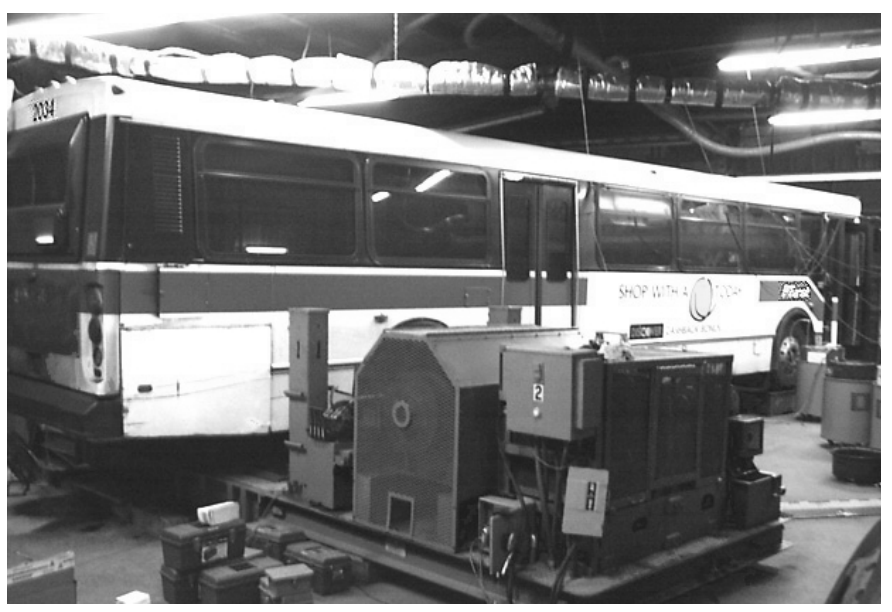

Figure 3. Pittsburgh 6V-92 Bus Mounted on the Test Bed

The six buses employed in this program were full size 40foot transit buses in service in Pittsburgh, PA. The engines were all 6V-92 Detroit Diesel two stroke units, rated at $253 \mathrm{hp}$. Three of the buses had engines that had seen on average over 300,000 miles of service, while three of the buses were equipped with recently rebuilt engines with oxidizing catalysts. The buses had 4-speed automatic transmissions and were tested at a 32,990 lb test weight. The emissions were characterized using three fuels, a BP 49-state diesel purchased at the pump (D2), South Africa Mossgas Fischer-Tropsch derived diesel fuel (FT-MGCOD), and a 50/50 blend of these two fuels (FT-MGCOD50/D2-50).

\section{FUEL USED}

The trucks were characterized using a California \#2 Diesel (CAD), Malaysia Fischer-Tropsch fuel (FT-SMD), and a $50 / 50$ blend of the these two fuels (FT-SMD50/ CAD50), while the buses were characterized using a 49 state diesel (D2), South Africa Mossgas Fischer-Tropsch 
derived fuel (FT-MGCOD) and a 50/50 blend of these two fuels (FT-MGCOD50/D2-50). The Malaysian FT-SMD fuel offered a high degree of saturation and vanishingly low aromatics, while the Mossgas FT-MGCOD fuel had aromatics at the $10 \%$ level, which is still considerably lower than aromatic levels in present day U. S. diesel fuels. Both the FT-SMD and FT-MGCOD were used with a lubricity additive (Paradyne, $0.02 \%$ by volume) and the $50 / 50$ mix had one half of this additive level. Table 1 shows the properties that are known for the fuels.

Table 1. Fuel Analysis for the Fuels Used in This Study

\begin{tabular}{|c|c|c|c|c|}
\hline & \multicolumn{2}{|c|}{ For Pima Gro truck tests } & \multicolumn{2}{|c|}{ For $6 \mathrm{~V}-92$ transit bus tests } \\
\hline Analysis & $\begin{array}{c}\text { California D2 } \\
\text { (CAD) }\end{array}$ & $\begin{array}{c}\text { Malaysia F-T } \\
\text { (FT-SMD) }\end{array}$ & $\begin{array}{l}49 \text { state Diesel } \\
\text { (D2) }\end{array}$ & $\begin{array}{l}\text { Mossgas F-T } \\
\text { (FT-MGCOD) }\end{array}$ \\
\hline \multicolumn{5}{|l|}{ Distillation (\% v/v) } \\
\hline Initial Boiling Pt. $\left({ }^{\circ} \mathrm{C}\right)$ & 175 & & 193 & \\
\hline $5 \%\left({ }^{\circ} \mathrm{C}\right)$ & 202 & & 208 & \\
\hline $50 \%\left({ }^{\circ} \mathrm{C}\right)$ & 268 & & 261 & \\
\hline $90 \%\left({ }^{\circ} \mathrm{C}\right)$ & 332 & & 312 & 321.1 \\
\hline F.B.P $\left({ }^{\circ} \mathrm{C}\right)$ & 363 & & 336 & 360.8 \\
\hline Recovery (\% vol) & 99.5 & & 98.5 & \\
\hline Residue (\% vol) & 0.5 & & 1.5 & \\
\hline Loss (\% vol) & 0 & & 0 & \\
\hline Density, kg/L@15C & 0.8329 & 0.7845 & & 0.8007 \\
\hline API Gravity @ 60F (API) & & 54 & 37.4 & \\
\hline Cetane No. & 53.7 & 73.7 & 48.7 & 51.4 \\
\hline Sulfur Content (\% mass) & 0.01 & * & & $<0.001$ \\
\hline \multicolumn{5}{|l|}{ Heat of Combustion } \\
\hline Gross Heat Value (BTU/gal) & 136031 & 132716 & 137609 & 130955 \\
\hline Net Heat Value (BTU/gal) & 127828 & 123615 & 129147 & 122937 \\
\hline Gross Heat Value (BTU/lb) & 19618 & 20273.8 & 19726 & 19600 \\
\hline Net Heat Value (BTU/lb)] & 18435 & 18883.5 & 18513 & 11400 \\
\hline Aromatic (\% v/v) & 18.1 & 0.1 & 24.7 & 10.1 \\
\hline Saturates (\% v/v) & & 99.8 & 73.8 & \\
\hline Olefins $(\% \mathrm{v} / \mathrm{v})$ & & 0.1 & 1.5 & \\
\hline Flash Point $\left({ }^{\circ} \mathrm{C}\right)$ & & 72 & & 100 \\
\hline Cloud Point $\left({ }^{\circ} \mathrm{C}\right)$ & & 3 & & \\
\hline Water \& Sediment (\%) & & $<0.02$ & & $<0.01$ \\
\hline Carbon Residue (\% mass) & & 0.02 & & \\
\hline Ash (\% mass) & & $<0.001$ & & $<0.01$ \\
\hline Viscosity (cSt @ 40 & & 3.57 & & 2.974 \\
\hline Corrosion & & $1 \mathrm{~A}$ & & $1 \mathrm{~A}$ \\
\hline Pour Point $\left({ }^{\circ} \mathrm{C}\right)$ & & 0 & & \\
\hline Gums \& Resins (mg/100ml) & & 0.2 & & \\
\hline Lubricity SDBOCLS (grams) & & 1700 & & \\
\hline Lubricity HFRR (micron) & & $420 / 540 / 570$ & & \\
\hline \multicolumn{5}{|l|}{ Carbon/Hydrogen (\% mass) } \\
\hline Carbon & & 84.91 & 86.11 & 85.30 \\
\hline Hydrogen & & 14.94 & 13.37 & 14.70 \\
\hline Nitrogen & & 0.57 & $<0.03$ & \\
\hline Residual & & -1.09 & & \\
\hline Oxygen (by difference) & & Negligible & & \\
\hline
\end{tabular}

* Considered to be vanishingly low, but reported as $<0.05 \%$. 


\section{TEST RESULTS AND DISCUSSION}

Table 2 shows an example of the repeatability from run to run of a Pima Gro tractor, exercised through the 5-Mile route. It is typical for a diesel vehicle to find that $\mathrm{NO}_{\mathrm{x}}$ and $\mathrm{CO}_{2}$ data are very repeatable, while $\mathrm{CO}$ and PM are highly sensitive to driving style. Although quality control measures for heavy duty vehicle chassis dynamometer are under examination [13], in the present research, only the total distance driven was monitored for repeatability of driver performance.
Table 3 summarizes the data for the Pima Gro trucks operated on California diesel and Malaysia FischerTropsch (FT-SMD) fuel. Each line in the table represents the average of at least four runs. Figure 4 and Table 4 highlight the differences in emissions levels between the two fuels. The FT-SMD fuel showed benefits across the board in reducing regulated emissions, reducing PM by $25 \%$ and $\mathrm{NO}_{\mathrm{x}}$ by $12 \%$. However, it was noted that the four vehicles tested were not uniform in their $\mathrm{NO}_{x}$ and $\mathrm{PM}$ reduction.

Table 2. Typical test repeatability from a CAD fuel using the 5-Mile route test

\begin{tabular}{|c|c|c|c|c|c|c|c|c|}
\hline \multicolumn{6}{|c|}{ Emissions results (g/mile) for CAD: } & \multicolumn{2}{|c|}{ Fuel Economy } & Distance \\
\hline Run Seq. No. & $\mathrm{CO}$ & $\mathrm{NO}_{\mathrm{x}}$ & FIDHC & PM & $\mathrm{CO}_{2}$ & Mile/gal & $\begin{array}{l}\text { BTU/ } \\
\text { mile }\end{array}$ & Miles \\
\hline $1167-1$ & 3.67 & 12.1 & 0.66 & 0.48 & 1789 & 5.66 & 22952 & 5.01 \\
\hline $1167-2$ & 4.24 & 12.1 & 0.59 & 0.48 & 1736 & 5.83 & 22285 & 5.00 \\
\hline $1167-3$ & 4.06 & 11.7 & 0.62 & 0.46 & 1695 & 5.97 & 21763 & 5.00 \\
\hline $1167-4$ & 3.83 & 12.0 & 0.61 & 0.47 & 1688 & 6.00 & 21670 & 5.01 \\
\hline $1167-5$ & 4.06 & 12.0 & 0.59 & 0.48 & 1671 & 6.06 & 21457 & 5.00 \\
\hline 1167 Average & 397 & 120 & 061 & 047 & 1716 & 591 & 22025 & 500 \\
\hline Std. Dev. & 0.22 & 0.1 & 0.03 & 0.01 & 47 & 0.16 & 601 & 0.00 \\
\hline CV\% & 5.6 & 1.2 & 4.6 & 1.4 & 2.7 & 2.7 & 2.7 & 0.1 \\
\hline
\end{tabular}

Table 3. Average emissions (in grams/mile) and fuel economy from Pima Gro tractors operating on CAD and FT-SMD

\begin{tabular}{|c|c|c|c|c|c|c|c|c|c|}
\hline Test ID & Vehicle \# & Fuel & $\mathrm{CO}$ & $\mathrm{NO}_{\mathrm{x}}$ & FIDHC & PM & $\mathrm{CO}_{2}$ & MPG & BTU/mile \\
\hline 1193 & 2011 & CAD & 2.8 & 14.58 & 0.66 & 0.37 & 1426 & 7.11 & 18300 \\
\hline 1172 & 2012 & CAD & 5.0 & 13.99 & 0.52 & 0.50 & 1863 & 5.44 & 23926 \\
\hline 1223 & 2016 & CAD & 4.3 & 12.84 & 0.89 & 0.59 & 1755 & 5.77 & 22541 \\
\hline \multirow[t]{4}{*}{1167} & 2019 & CAD & 4.0 & 11.98 & 0.61 & 0.47 & 1716 & 5.91 & 22025 \\
\hline & & Average: & 4.0 & 13.35 & 0.67 & 0.48 & 1690 & 6.05 & 21698 \\
\hline & & Std. Dev. & 0.9 & 1.16 & 0.16 & 0.09 & 187 & 0.73 & 2403 \\
\hline & & CV\% & $23 \%$ & $9 \%$ & $24 \%$ & $19 \%$ & $11 \%$ & $12 \%$ & $11 \%$ \\
\hline 1191 & 2011 & FT-SMD & 2.6 & 11.25 & 0.41 & 0.35 & 1393 & 6.62 & 18701 \\
\hline 1173 & 2012 & FT-SMD & 3.9 & 13.71 & 0.33 & 0.30 & 1709 & 5.38 & 22949 \\
\hline 1221 & 2016 & FT-SMD & 3.2 & 11.24 & 0.50 & 0.48 & 1634 & 5.63 & 21947 \\
\hline \multirow[t]{4}{*}{1170} & 2019 & FT-SMD & 3.5 & 10.65 & 0.36 & 0.33 & 1645 & 5.59 & 22083 \\
\hline & & Average: & 3.3 & 11.71 & 0.40 & 0.36 & 1595 & 5.81 & 21420 \\
\hline & & Std. Dev. & 0.6 & 1.36 & 0.07 & 0.08 & 139 & 0.55 & 1866 \\
\hline & & CV\% & $17 \%$ & $12 \%$ & $19 \%$ & $21 \%$ & $9 \%$ & $10 \%$ & $9 \%$ \\
\hline
\end{tabular}

Table 4. Average emissions comparison between CAD and FT-SMD for four Pima Gro tractors

\begin{tabular}{|c|c|c|c|c|c|}
\hline Fuel & $\mathbf{C O}$ & $\mathbf{N O}_{\mathbf{x}}$ & $\mathbf{F I D H C}$ & $\mathbf{P M}$ & $\mathbf{C O}_{\mathbf{2}}$ \\
\hline CAD & 4.0 & 13.35 & 0.67 & 0.48 & 1690 \\
\hline FT-SMD & 3.3 & 11.71 & 0.40 & 0.36 & 1595 \\
\hline$\%$ Reduction & $18 \%$ & $12 \%$ & $40 \%$ & $25 \%$ & $6 \%$ \\
\hline
\end{tabular}

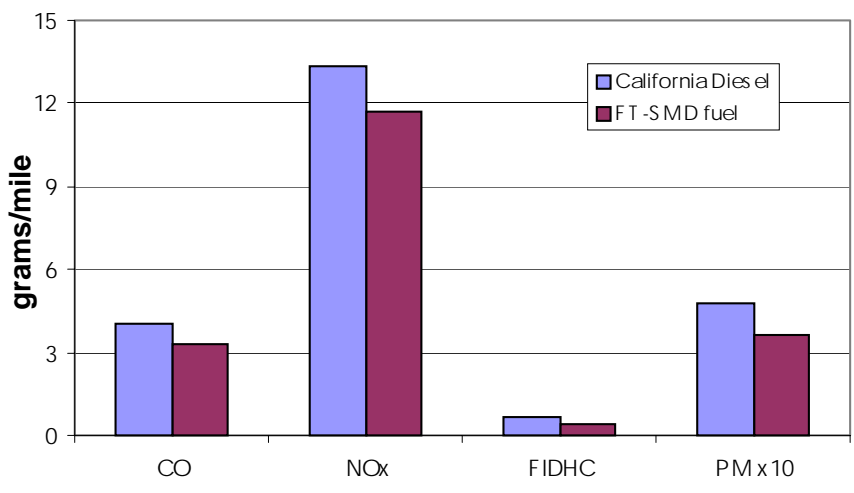

Figure 4. Average emissions comparison between CAD and FT-SMD from four Pima Gro tractors 
Figure 5 and Tables 5 and 6 compare the California diesel and 50/50 blend data. Once again, the blend benefited regulated emissions across the board relative to the present day California fuel. Although the authors disfavor reaching general conclusions from a small sample of trucks, benefits were reduced by about $50 \%$ as a result of the $50 \%$ dilution, except in the case of $\mathrm{NO}_{x}$, where the percentage improvement was similar to that for pure FTSMD. In reviewing this data, the reader should note that California diesel fuel is already formulated to have lower emissions than 49-state fuel through reduction of aromatic content: one might expect greater advantages of the FT-SMD fuel in comparison to 49-state D2 fuel.

Table 5. Average emissions (in grams/mile) and fuel economy from Pima Gro tractors on CAD and FT-SMD50

\begin{tabular}{|c|c|c|c|c|c|c|c|c|c|}
\hline Test ID & Vehicle \# & Fuel & $\mathrm{CO}$ & $\mathrm{NO}_{\mathrm{x}}$ & FIDHC & PM & $\mathrm{CO}_{2}$ & MPG & BTU/mile \\
\hline 1193 & 2011 & CAD & 2.8 & 14.58 & 0.66 & 0.37 & 1426 & 7.11 & 18300 \\
\hline 1223 & 2016 & CAD & 4.3 & 12.84 & 0.89 & 0.59 & 1755 & 5.77 & 22541 \\
\hline \multirow{4}{*}{1209} & 2017 & CAD & 4.8 & 13.28 & 0.69 & 0.61 & 1784 & 5.67 & 22920 \\
\hline & & Average: & 3.9 & 13.57 & 0.75 & 0.52 & 1655 & 6.18 & 21254 \\
\hline & & Std. Dev. & 1.0 & 0.91 & 0.13 & 0.13 & 199 & 0.80 & 2565 \\
\hline & & CV\% & $27 \%$ & $7 \%$ & $17 \%$ & $26 \%$ & $12 \%$ & $13 \%$ & $12 \%$ \\
\hline 1190 & 2011 & FT-SMD50 & 2.5 & 10.58 & 0.51 & 0.38 & 1438 & 6.65 & 19053 \\
\hline 1222 & 2016 & FT-SMD50 & 3.7 & 11.77 & 0.72 & 0.59 & 1717 & 5.57 & 22774 \\
\hline \multirow[t]{4}{*}{1210} & 2017 & FT-SMD50 & 4.2 & 14.03 & 0.44 & 0.40 & 1621 & 5.89 & 21512 \\
\hline & & Average: & 3.5 & 12.13 & 0.56 & 0.46 & 1592 & 6.04 & 21113 \\
\hline & & Std. Dev. & 0.9 & 1.75 & 0.15 & 0.11 & 142 & 0.56 & 1892 \\
\hline & & CV\% & $25 \%$ & $14 \%$ & $27 \%$ & $25 \%$ & $9 \%$ & $9 \%$ & $9 \%$ \\
\hline
\end{tabular}

Table 6. Average emissions comparison between CAD and FT-SMD50 for three Pima Gro tractors

\begin{tabular}{|c|c|c|c|c|c|}
\hline Fuel & $\mathbf{C O}$ & $\mathbf{N O}_{\mathbf{x}}$ & $\mathbf{F I D H C}$ & $\mathbf{P M}$ & $\mathbf{C O}_{\mathbf{2}}$ \\
\hline CAD & 3.9 & 13.57 & 0.75 & 0.52 & 1655 \\
\hline FT-SMD50 & 3.5 & 12.13 & 0.56 & 0.46 & 1592 \\
\hline$\%$ Reduction & $10 \%$ & $11 \%$ & $25 \%$ & $12 \%$ & $4 \%$ \\
\hline
\end{tabular}

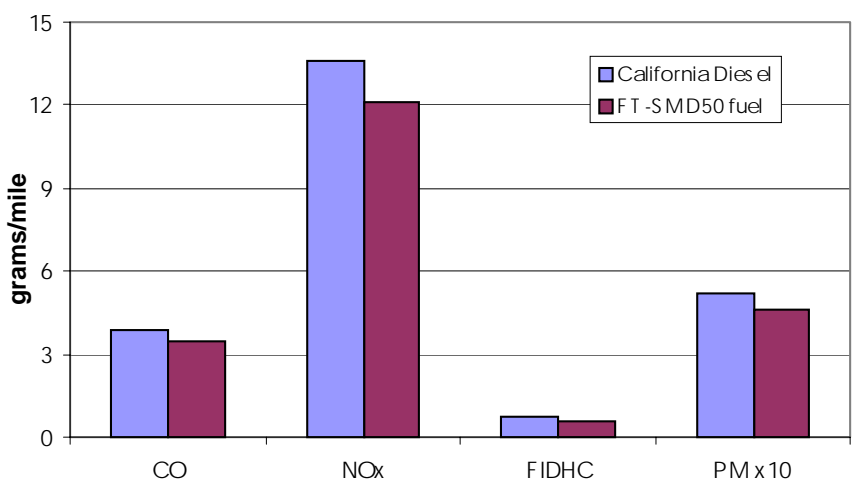

Figure 5. Average emissions comparison between CAD and FT-SMD50 from three Pima Gro tractors

Tables 7 and 8 and Figures 6 and 7 present emissions data for the Pittsburgh buses, tested using the CBD cycle, on 49-state diesel (D2), Mossgas fuel (FTMGCOD), and 50/50 blend of these (FT-MGCOD50). The catalyst and non-catalyst buses have been separated because their emissions of $\mathrm{CO}, \mathrm{HC}$ and PM differed substantially. Bus 2029 appears in both groups because the chassis was retrofitted with a rebuilt engine and fitted with a catalyst during the program. Its emissions were characterized both before and after the retrofit.
The catalyst and non-catalyst buses had similar levels of $\mathrm{NO}_{x}$ emissions. In both cases the FT-MGCOD offered a small $\mathrm{NO}_{\mathrm{x}}$ reduction relative to the 49-state diesel, and there was also an advantage in stepping from 49-state diesel to the 50/50 blend. Although $\mathrm{HC}, \mathrm{CO}$ and PM were substantially lower for the catalyst than the non-catalyst buses, all six buses showed the benefit of the FTMGCOD and the blend in reducing $\mathrm{HC}, \mathrm{CO}$ and $\mathrm{PM}$. The average PM reported for the buses without aftertreatment must be carefully considered, because one of these buses was a far higher emitter than the other two. The combination of FT-MGCOD fuel, engine rebuild and catalyst addition on the city buses had the effect of reducing $\mathrm{NO}_{x}$ by $14 \%$, CO more than 20 -fold, $\mathrm{HC}$ by a factor of four and PM by a factor of four.

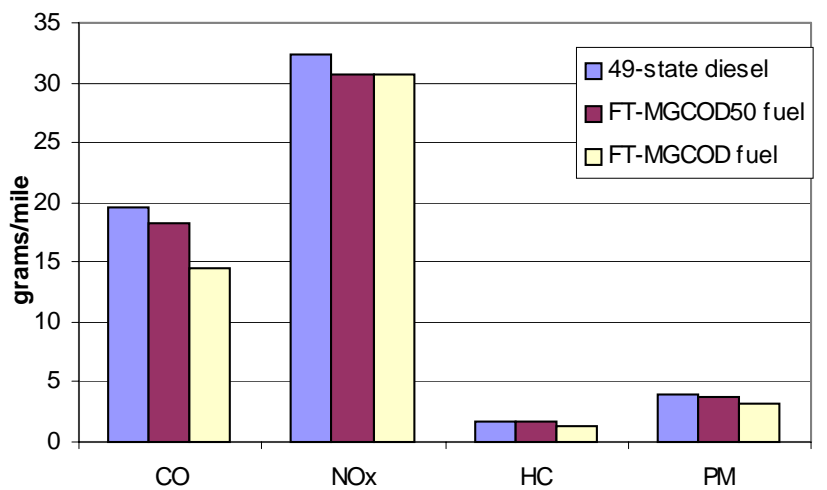

Figure 6. Average emissions comparison between D2, FT-MGCOD and their blend from three Pittsburgh transit buses without catalytic converters 


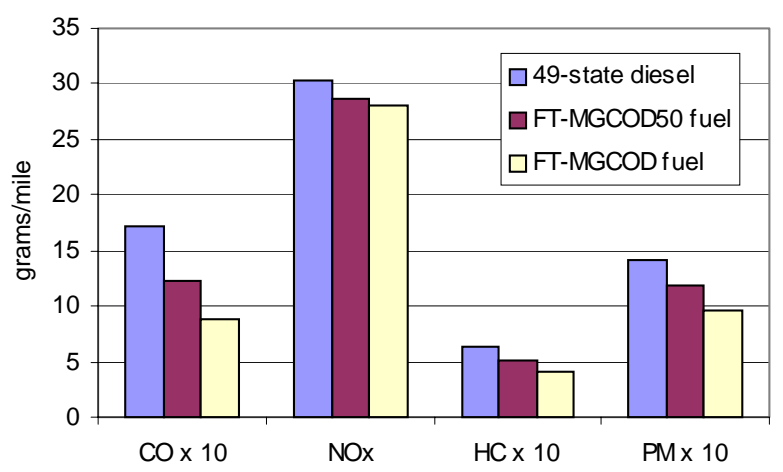

Figure 7. Average emissions comparison between D2, FT-MGCOD and their blend from three Pittsburgh transit buses with catalytic converter
Table 7. Average emissions comparison between D2, FT-MGCOD and their blend from five Pittsburgh transit buses

\begin{tabular}{|c|c|c|c|c|c|}
\hline & Fuel & $\mathrm{CO}$ & $\mathrm{NO}_{\mathrm{x}}$ & HC & PM \\
\hline \multirow{4}{*}{$\begin{array}{c}\text { With } \\
\text { Catalytic } \\
\text { Converter }\end{array}$} & 49-state & 1.711 & 30.3 & 0.63 & 1.41 \\
\hline & & .220 . & 28.67 & 0.51 & 1.19 \\
\hline & & 87 & 28.00 & 0.41 & 0.97 \\
\hline & $\begin{array}{l}\text { \% reducti } \\
\% \text { reducti }\end{array}$ & & $\begin{array}{l}6 \% \\
8 \%\end{array}$ & $\begin{array}{l}9 \% \\
5 \%\end{array}$ & $\begin{array}{l}16 \% \\
31 \%\end{array}$ \\
\hline \multirow{5}{*}{$\begin{array}{l}\text { Without } \\
\text { Catalytic } \\
\text { Converter }\end{array}$} & & 19.60 & 32.33 & 1.75 & 4.00 \\
\hline & T-N & 18.16 & 30.72 & 1.63 & 3.75 \\
\hline & & 14.42 & 30.64 & 1.40 & 3.19 \\
\hline & & $7 \%$ & $5 \%$ & $7 \%$ & $6 \%$ \\
\hline & & $26 \%$ & $5 \%$ & $20 \%$ & $20 \%$ \\
\hline
\end{tabular}

Table 8. Average emissions (in grams/mile) and fuel economy from Pittsburgh 6V-92 transit buses on D2, FT-MGCOD and their blend

\begin{tabular}{|c|c|c|c|c|c|c|c|c|c|}
\hline & Fuel & Bus \# & $\mathrm{CO}$ & $\mathrm{NO}_{\mathbf{x}}$ & HC & PM & $\mathrm{CO}_{2}$ & MPG & BTU/mile \\
\hline \multirow{12}{*}{$\begin{array}{c}\text { Buses with } \\
\text { Catalytic Converters }\end{array}$} & \multirow{3}{*}{$\begin{array}{l}\text { 49-state } \\
\text { Diesel }\end{array}$} & 2025 & 1.96 & 34.51 & 0.75 & 1.23 & 4355 & 2.33 & 55713 \\
\hline & & 2029 & 1.07 & 26.91 & 0.39 & 1.89 & 4458 & 2.28 & 56995 \\
\hline & & 2048 & 2.11 & 29.71 & 0.75 & 1.12 & 3451 & 2.94 & 44159 \\
\hline & & Average: & 1.71 & 30.38 & 0.63 & 1.41 & 4088 & 2.52 & 52289 \\
\hline & \multirow{3}{*}{$\begin{array}{c}\text { FT-MGCOD50 } \\
\text { Diesel }\end{array}$} & 2025 & 1.34 & 31.93 & 0.54 & 1.14 & 4360 & 2.20 & 57589 \\
\hline & & 2029 & 0.81 & 26.40 & 0.40 & 1.59 & 4346 & 2.21 & 57391 \\
\hline & & 2048 & 1.51 & 27.69 & 0.59 & 0.83 & 3381 & 2.84 & 44672 \\
\hline & & Average: & 1.22 & 28.67 & 0.51 & 1.19 & 4029 & 2.42 & 53217 \\
\hline & \multirow{3}{*}{$\begin{array}{l}\text { FT-MGCOD } \\
\text { Diesel }\end{array}$} & 2025 & 1.02 & 31.37 & 0.44 & 1.01 & 4206 & 2.19 & 56272 \\
\hline & & 2029 & 0.75 & 26.10 & 0.29 & 1.16 & 4181 & 2.21 & 55928 \\
\hline & & 2048 & 0.82 & 26.53 & 0.49 & 0.76 & 3338 & 2.77 & 44659 \\
\hline & & Average: & 0.87 & 28.00 & 0.41 & 0.97 & 3908 & 2.39 & 52286 \\
\hline \multirow{12}{*}{$\begin{array}{c}\text { Buses without } \\
\text { Catalytic Converters }\end{array}$} & \multirow{3}{*}{$\begin{array}{l}\text { 49-state } \\
\text { Diesel }\end{array}$} & 2029 & 11.73 & 35.85 & 1.82 & 1.79 & 4328 & 2.34 & 55598 \\
\hline & & 2030 & 6.65 & 34.88 & 2.11 & 1.18 & 4149 & 2.44 & 53221 \\
\hline & & 2034 & 40.42 & 26.26 & 1.31 & 9.03 & 4900 & 2.05 & 63468 \\
\hline & & Average: & 19.60 & 32.33 & 1.75 & 4.00 & 4459 & 2.28 & 57429 \\
\hline & \multirow{3}{*}{$\begin{array}{c}\text { FT-MGCOD50 } \\
\text { Diesel }\end{array}$} & 2029 & 10.33 & 32.23 & 1.88 & 1.52 & 4348 & 2.20 & 57601 \\
\hline & & 2030 & 6.26 & 33.93 & 2.03 & 1.13 & 4099 & 2.34 & 54244 \\
\hline & & 2034 & 37.91 & 26.02 & 0.99 & 8.61 & 4704 & 2.02 & 62887 \\
\hline & & Average: & 18.16 & 30.72 & 1.63 & 3.75 & 4383 & 2.18 & 58244 \\
\hline & \multirow{3}{*}{$\begin{array}{l}\text { FT-MGCOD } \\
\text { Diesel }\end{array}$} & 2029 & 11.02 & 33.37 & 1.72 & 1.34 & 4392 & 2.09 & 58963 \\
\hline & & 2030 & 5.73 & 32.92 & 1.75 & 1.16 & 4133 & 2.23 & 55391 \\
\hline & & 2034 & 26.52 & 25.64 & 0.72 & 7.07 & 4639 & 1.97 & 62596 \\
\hline & & Average: & 14.42 & 30.64 & 1.40 & 3.19 & 4388 & 2.10 & 58984 \\
\hline
\end{tabular}




\section{CONCLUSIONS}

Two separate emissions studies using a chassis dynamometer have been used to evaluate novel compression ignition fuels. Fischer-Tropsch fuel offered advantages in reducing all of the regulated emissions $(\mathrm{CO}, \mathrm{HC}, \mathrm{PM}$ and $\mathrm{NO}_{\mathrm{x}}$ ) relative to California \#2 diesel for Class 8 over-theroad tractors exercised through the 5-Mile route at a test weight of $42,000 \mathrm{lbs}$. Similarly, a fuel from Mossgas, containing approximately $10 \%$ aromatics, yielded lower levels of all regulated emissions than 49 state diesel when tested over the CBD cycle on transit buses, both with and without catalytic aftertreatment devices. This study has highlighted the benefits of compression ignition fuels with reformulated compositions under in-use driving conditions, and has shown that fuels derived using gas-to-liquid processing offer promise from an environmental perspective.

\section{ACKNOWLEDGMENTS}

The authors are grateful to the staff of the WVU Transportable Heavy Duty Vehicle Emissions Testing Laboratories for their work in the field and to the vehicle owners for their assistance with the testing. The study was funded by the U. S. Department of Energy, Office of Transportation Technologies.

\section{REFERENCES}

1. Nine, R.D., Clark, N.N., Mace, B.D., Morrison, R.W., Remcho, V.T., Lowe, P.C. and McLaughlin, L.W., "Use of Soy-Derived Fuel for Environmental Impact Reduction in Marine Engine Applications", American Society of Agricultural Engineers Annual Meeting, Orlando, FI., 1998, ASAE Paper 986083.

2. Zhang, Y. and Van Gerpen, J.H., "Combustion Analysis of Esters of Soybean Oil in a Diesel Engine", SAE Paper 960795, 1996.

3. Mann, N., Kvinge, F., and Wilson, G., "Diesel Fuel Effects on Emissions: Towards a Better Understanding," SAE Paper No. 982486, 1998.

4. Brown, S. J., "An Experimental Investigation of Affordable Alternative Fuel and Exhaust Aftertreatment Options for Urban Busses," Proceedings of the Trucks and Buses: The Result of Real-World Emission Testing, Millbrook Proving Grounds, U. K., December 1997.

5. Sirman, M., Owens, E. C., and Whitney, K. A., "Emissions Comparisons of Alternative Fuels in an Advanced Automotive Diesel Engine," Interim Report TFLRF No. 338, Department of Energy, Contract No. DAAK70-92-C-0059, 1998.

6. Schaberg, P., Myburgh, I., Botha, J., Roets, P., Viljoen, C., Dancuart, L., and Starr, M., "Diesel Exhaust Emissions Using Sasol Slurry Phase Distillate Process Fuels," SAE Paper No. 972898, 1997.
7. Norton, P., Bailey, B. K., Goguen, S. J., Vertin, K. D., Clark, N. N., Lyons, D. W., Eberhardt, J. J., "Emissions from Trucks using Fischer-Tropsch Diesel Fuel", SAE Paper No. 982526, 1998.

8. Chandler, K. L., Norton, P., Clark, N. N., "Interim Results from Alternative Fuel Truck Evaluation Project", SAE Paper No. 1999-01-1505, 1999.

9. Norton, P., Vertin, K. D., Clark, N. N., Lyons, D. W., Goguen, S. J., Eberhardt, J., "Emissions from Buses with DDC 6V92 Engines using Fischer-Tropsch Diesel Fuel", SAE Paper No. 1999-01-1512, 1999.

10. Clark. N. N., Gautam, M., Bata, R- M., and Lyons, D. W., "Design and Operation of a New Transportable Laboratory for Emissions Testing of Heavy Duty Trucks and Buses", International Journal of Vehicle Design: Heavy Vehicle Systems, Vol. 2, Nos. 3/4, pp. 285-299. 1995.

11. Clark, N. N., McKain, D. L., Messer, T. J., and Lyons, D., W., "Chassis Test Cycles for Assessing Emissions from Heavy Duty Trucks", SAE Paper 941946, 1994.

12. Clark, N. N., Messer, T. J.,, McKain, D. L., Wang, W. G., Bata, R. M., Gautam, M., and Lyons, D. W., "Use of the West Virginia University Truck Test Cycle to Evaluate Emissions from Class 8 Trucks", SAE Paper 951016, 1995.

13. McKain, D. L. and Clark, N. N., "Speed and Power Regressions for Quality Control of Heavy Duty Vehicle Chassis Dynamometer Research", SAE Paper 1999-01-0614, 1999. 